\title{
Giant prolactinomas in women
}

\author{
Etienne Delgrange, Gerald Raverot ${ }^{1}$, Marie Bex ${ }^{2}$, Pia Burman ${ }^{3}$, \\ Bénédicte Decoudier ${ }^{4}$, France Devuyst ${ }^{5}$, Ulla Feldt-Rasmussen ${ }^{6}$, \\ Marianne Andersen ${ }^{7}$ and Dominique Maiter ${ }^{8}$
}

Service d'Endocrinologie, Centre Hospitalier Universitaire de Mont-Godinne, Université Catholique de Louvain, B-5530 Mont-sur-Meuse, Belgium, 'Fédération d'Endocrinologie, Groupement Hospitalier Est, Hospices Civils de Lyon et INSERM U 1028, Université de Lyon, Lyon, France, ${ }^{2}$ Department of Endocrinology, University Hospitals Leuven, Leuven, Belgium, ${ }^{3}$ Department of Endocrinology, Skanes University Hospital Malmo, University of Lund, Lund, Sweden, ${ }^{4}$ Service d'Endocrinologie, Centre Hospitalier Universitaire de Reims, Reims, France,

${ }^{5}$ Service d'Endocrinologie, Hôpital Erasme, Université Libre de Bruxelles, Bruxelles, Belgium,

${ }^{6}$ Department of Medical Endocrinology, Rigshospitalet, Copenhagen University Hospital, Copenhagen, Denmark, ${ }^{7}$ Department of Endocrinology, Odense University Hospital, Odense, Denmark and ${ }^{8}$ Service d'Endocrinologie et Nutrition, Cliniques Universitaires Saint-Luc, Université Catholique de Louvain, Bruxelles, Belgium

Correspondence should be addressed to E Delgrange Email etienne.delgrange@uclouvain.be

\begin{abstract}
Objective: To characterise distinctive clinical features of giant prolactinomas in women.

Design: A multicentre, retrospective case series and literature review.
\end{abstract}

Methods: We collected data from 15 female patients with a pituitary tumour larger than $4 \mathrm{~cm}$ and prolactin levels above $1000 \mu \mathrm{g} / \mathrm{l}$ and identified 19 similar cases from the literature; a gender-based comparison of the frequency and age distribution was obtained from a literature review.

Results: The initial PubMed search using the term 'giant prolactinomas' identified 125 patients ( 13 women) responding to the inclusion criteria. The female:male ratio was 1:9. Another six female patients were found by extending the literature search, while our own series added 15 patients. The median age at diagnosis was 44 years in women compared with 35 years in men $(P<0.05)$. All cases diagnosed before the age of 15 years were boys. In women $(n=34)$, we observed a minor peak incidence during the third decade of life and a major peak during the fifth decade. Amenorrhoea was a constant feature with seven cases of primary amenorrhoea. In eight women with onset of secondary amenorrhoea before the age of 40 years, the diagnosis was made 2-31 years later (median 9 years) and in all but one because of tumour pressure symptoms. The prolactin levels were above $10000 \mu \mathrm{g} / \mathrm{l}$ in 15/34 and misdiagnosis due to 'hook effect' occurred in two of them. Eighteen patients were treated with cabergoline; standard doses ( $<2.0 \mathrm{mg} /$ week) were able to normalise prolactin in only $4 / 18$ patients, and $7 / 18$ patients were resistant to weekly doses ranging from 3.0 to $7.0 \mathrm{mg}$.

Conclusion: Giant prolactinomas are rare in women, often resistant to dopamine agonists and seem to be distributed in two age groups, with a larger late-onset peak.

\section{Introduction}

Prolactinomas represent the most common type of pituitary adenoma in women. These tumours classically present with amenorrhoea, infertility and galactorrhoea in premenopausal women and are usually intrasellar at diagnosis. Tumours larger than $4 \mathrm{~cm}$, so-called 'giant prolactinomas', are extremely rare in women and most published series of giant prolactinomas include only men
$(1,2,3)$. This is generally attributed to an early detection of the disease, easily identified by endocrine symptoms in women. Cabergoline is recommended as first-line treatment, resulting in significant tumour shrinkage in most cases (4). In non-surgical series, due to the absence of histological confirmation of the diagnosis, diagnostic criteria for giant prolactinomas include not only tumour
(C) 2014 European Society of Endocrinology Printed in Great Britain
Published by Bioscientifica Ltd. 
extension but also serum prolactin levels, which generally parallel tumour size. As large invasive prolactinomas are characterised by serum prolactin levels $>1000 \mu \mathrm{g} / \mathrm{l}$ (5), and a similar figure is used in most recent series to define giant prolactinomas $(1,3,4)$.

We have collected original data from 15 female patients with tumours larger than $4 \mathrm{~cm}$ and prolactin levels above $1000 \mu \mathrm{g} / \mathrm{l}$, and 19 similar cases were identified in the literature. In this report, the frequency distribution of giant prolactinomas by age and gender will be presented and the distinctive clinical characteristics of these rare tumours in females will be discussed.

\section{Subjects and methods}

\section{Case finding}

This was a collaborative, retrospective study involving several academic centres from Belgium, Denmark, France and Sweden. All centres were asked to include data from all women with a giant prolactinoma seen between 1992 and 2012. All patients met the diagnostic criteria generally accepted for giant prolactinoma $(1,3,4)$, i.e. a tumour diameter $\geq 40 \mathrm{~mm}$ and serum prolactin levels above $1000 \mu \mathrm{g} / \mathrm{l}$ without features of acromegaly or Cushing's syndrome.

\section{Literature review}

The PubMed database was searched at the end of December 2012 using the term 'giant prolactinomas'. Only articles written in English were selected $(n=99)$. Review articles were excluded as well as reports with insufficient detail to allow a correct compilation of individual data concerning gender, age at presentation, tumour diameter and PRL levels. From the remaining articles $(n=68)$, subjects with a giant prolactinoma, defined using the above-mentioned criteria, were included to compare the age distribution of these tumours between genders.

The literature review was extended from the references of these reports and by searching PubMed, in females, using additional terms such as 'prolactin hook effect, invasive prolactinomas, prolactinomas and hydrocephalus, prolactinomas and epilepsy, prolactinomas and cerebrospinal fluid leakage'. Data from our 15 patients and from the literature review were analysed to determine age at presentation, initial PRL level, maximum tumour diameter, clinical presentation, duration of symptoms prior to diagnosis, treatment, maximal dopamine agonist
(DA) treatment dose, nadir PRL level and final tumour size. Prolactin values expressed as $\mathrm{mU} / \mathrm{l}$ were converted to $\mu \mathrm{g} / \mathrm{l}$ using a conversion factor of 21 . Medians were compared using the non-parametric Mann-Whitney $U$ test and the level of significance was set at $P<0.05$.

\section{Results}

The initial PubMed search identified 125 patients with a pituitary tumour larger than $40 \mathrm{~mm}$ and serum prolactin levels $>1000 \mu \mathrm{g} / \mathrm{l}$. There were 112 men and 13 women (10\%) $(6,7,8,9,10,11,12)$ (Table 1 , case nos 1-13).

The extended literature search identified another six female patients $(13,14,15,16,17,18)$ (Table 1 , case nos 14-19) while our own series added 15 patients (Table 2), bringing the total female population to 34 patients. Their median age at diagnosis was 44 years (range 16-87 years) compared with 35 years in the reported 112 men (range $7-80$ years) $(P<0.05)$. The distribution of giant prolactinomas by gender and decades of life is presented in Fig. 1. Men showed a unimodal and relatively symmetric distribution with a peak during the fourth decade of life. In women, the distribution seemed bimodal with a minor peak incidence during the third decade and a major peak during the fifth decade. The median age of the ten women with an early onset of the disease was 25 years (range 16-27) compared with 49 years (range 37-87) in the lateronset group of 24 women. All subjects aged $<15$ were diagnosed because of mass effects and were boys $(n=10)$.

When considering women alone, $(n=34$; Tables 1 and 2), the pre-treatment symptoms included amenorrhoea, galactorrhoea, visual disturbances and headache and also various symptoms related to the mass effects such as new onset of seizures, nasal congestion and exophthalmos. The tumour caused hydrocephalus in three cases (Table 1, case nos 15-17). One case was diagnosed as a pituitary incidentaloma after a head trauma (Table 2, case no. 6). Data regarding galactorrhoea and menstrual disturbances were available in 24 and 31 of the 34 women respectively. Galactorrhoea was present in eight of 24 patients and was never recorded after the age of 50 . Amenorrhoea was present in all 31 documented cases and was primary in seven cases. It was the presenting symptom in three cases diagnosed before the age of 20 , but in another three women the diagnosis was delayed until after the age of 40 , despite the presence of a primary amenorrhoea, so that the age at diagnosis in this group of patients ranged from 16 to 55. The age of onset of secondary amenorrhoea $(n=24)$ was not always mentioned and difficult to interpret when occurring after 
Table 1 Giant prolactinomas in women: data from the literature review.

\begin{tabular}{|c|c|c|c|c|c|c|c|c|}
\hline \multirow[b]{2}{*}{$\begin{array}{l}\text { Case } \\
\text { no. }\end{array}$} & \multirow[b]{2}{*}{ References } & \multirow[b]{2}{*}{$\begin{array}{l}\text { Age } \\
\text { (years) }\end{array}$} & \multirow[b]{2}{*}{ Presentation } & \multicolumn{2}{|c|}{ Prolactin level $(\mu \mathrm{g} / \mathrm{l})$} & \multirow[b]{2}{*}{$\begin{array}{l}\text { Tumour } \\
\text { size }(\mathrm{mm})\end{array}$} & \multirow[b]{2}{*}{$\begin{array}{l}\text { Dopamine agonist } \\
\text { (maximum dose) }\end{array}$} & \multirow[b]{2}{*}{$\begin{array}{l}\text { Surgery and/or } \\
\text { radiotherapy }\end{array}$} \\
\hline & & & & Initial & Latest & & & \\
\hline 1 & (6) & 48 & Headaches & 11381 & 9 & $>40$ & BRC (30 mg/day) & $\begin{array}{l}\text { S on BRC (personal } \\
\text { choice) }\end{array}$ \\
\hline 2 & (7), case 4 & 43 & $\begin{array}{l}\text { Weight gain } \\
\text { Visual defect } \\
\text { (amenor) }\end{array}$ & 15000 & 21 & 72 & BRC (10 mg/day) & \\
\hline 3 & (7), case 10 & 41 & $\begin{array}{l}\text { Visual defect } \\
\text { (amenor) }\end{array}$ & 13538 & 1700 & 70 & BRC (2.5 mg/day) & $\begin{array}{l}\text { S on BRC } \\
\text { (intolerance } \\
\text { to BRC) }\end{array}$ \\
\hline 4 & (8) & 25 & $\begin{array}{l}\text { Headaches } \\
\text { (amenor) }\end{array}$ & $\begin{array}{r}>16000 \\
(\text { hook })\end{array}$ & $\begin{array}{r}4950 \text { (after } \\
4 \text { weeks) }\end{array}$ & $>40$ & BRC (dose?) & \\
\hline 5 & (9), case 9 & 37 & Facial pain & $>8000$ & 226 & 75 & BRC (7.5 mg/day) & $\begin{array}{l}\text { RT on BRC } \\
\text { (intolerance } \\
\text { to } B R C \text { ) }\end{array}$ \\
\hline 6 & (9), case 14 & 25 & & 1100 & 312 & 42 & BRC (dose?) & \\
\hline 7 & (10) & 45 & Headaches & $\begin{array}{l}14640 \\
\text { (hook) }\end{array}$ & 1 & 50 & CAB (3 mg/week) & $\begin{array}{l}\mathrm{S} \text { and RT before } \mathrm{CAB} \\
\text { (misdiagnosis) }\end{array}$ \\
\hline & & & Visual defect & & & & & \\
\hline 8 & (11), case 1 & 50 & & 1256 & 13 & 40 & CAB (2 mg/week) & \\
\hline 9 & (11), case 2 & 17 & & 43163 & 14 & 45 & CAB (2 mg/week) & \\
\hline 10 & (11), case 3 & 40 & & 13700 & 3983 & 43 & CAB (3.5 mg/week) & \\
\hline 11 & (11), case 6 & 47 & & 2540 & 1278 & 40 & CAB (3 mg/week) & \\
\hline 12 & (11), case 10 & 25 & & 1961 & 7 & 42 & BRC (7.5 mg/day) & \\
\hline 13 & (12), case 32 & 44 & $\begin{array}{l}\text { Visual defect } \\
\text { Cranial nerve palsy }\end{array}$ & 1134 & 3 & $>40$ & BRC (10 mg/day) & \\
\hline 14 & (13) & 55 & $\begin{array}{l}\text { Visual defect } \\
\text { Nasal congestion }\end{array}$ & 33143 & 21 & $>40$ & BRC (30 mg/day) & \\
\hline 15 & (14) & 27 & Hydrocephalus & 8238 & 272 & $>40$ & BRC (dose?) & \\
\hline 16 & (15) & 44 & $\begin{array}{l}\text { Hydrocephalus } \\
\text { (primary amenor) }\end{array}$ & 9780 & 19 & $>40$ & BRC (5 mg/day) & \\
\hline 17 & (16) & 81 & Hydrocephalus & 6800 & 5 & $>40$ & BRC (30 mg/day) & \\
\hline 18 & (17), case 20 & 54 & & 4100 & 2 & 40 & Pergolide & \\
\hline 19 & (18) & 54 & Proptosis & 8723 & ND & 55 & BRC (dose?) & \\
\hline
\end{tabular}

Amenor, amenorrhoea; $\mathrm{CAB}$, cabergoline; BRC, bromocriptine; S, surgery; RT, radiotherapy; hook, hook effect.

the age of 40 , as the lack of menses could have resulted at that time from hyperprolactinaemia or from menopause. In eight women with onset of secondary amenorrhoea before the age of 40 years, the diagnosis of prolactinoma was made 2-31 years later (median 9 years) and in all but one because of tumour symptoms. In another three patients with a lesion revealed by tumour pressure symptoms, the amenorrhoea was masked by the use of oral contraceptives. Four patients were treated for osteoporosis (Table 2, case nos 2 and 11), including two who suffered from osteoporotic fractures (Table 2, case nos 6 and 14), probably related to long-standing amenorrhoea.

Tumour size ranged from 40 to $75 \mathrm{~mm}$ (median 44) and prolactin level from 1100 to $43163 \mu \mathrm{g} / \mathrm{l}$ (median 8723). The prolactin levels were $\geq 10000 \mu \mathrm{g} / \mathrm{l}$ in $15 / 34$ cases and misdiagnosis due to 'hook effect, occurred in two of them (Table 1, case nos 4 and 7). Cavernous sinus invasion was present in all except one patient (Table 2, case no. 1) from our own series.

All female patients $(n=34$; Tables 1 and 2$)$ were treated by DAs. Pergolide normalised the prolactin level in one case. Bromocriptine was used in 15 patients: prolactin levels did not normalise in eight, but the dose administered was unknown in four of them and $\leq 7.5 \mathrm{mg} /$ day in the other four patients, due to drug intolerance in two. In the seven patients with normalisation of prolactin levels, the daily bromocriptine dose ranged from 5 to $30 \mathrm{mg}$. The remaining 18 patients were treated with cabergoline, which was able to restore normoprolactinaemia in $10(55 \%)$. Four patients responded to standard doses ( $<2.0 \mathrm{mg} /$ week) (19) and six to doses ranging from 2.0 to $7.0 \mathrm{mg}$. Seven cases were resistant to the prolactin-lowering effect of cabergoline despite weekly doses of $3.0-7.0 \mathrm{mg}$, while one patient 


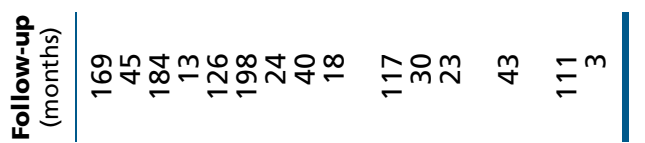
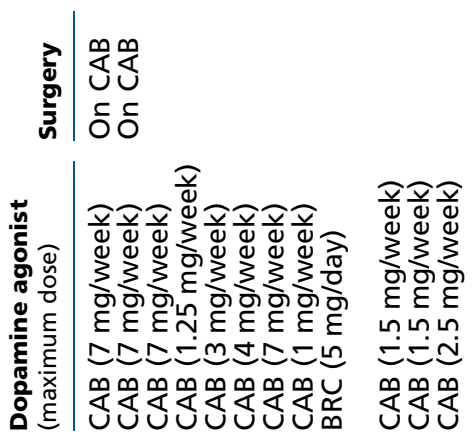

ঠั ธ
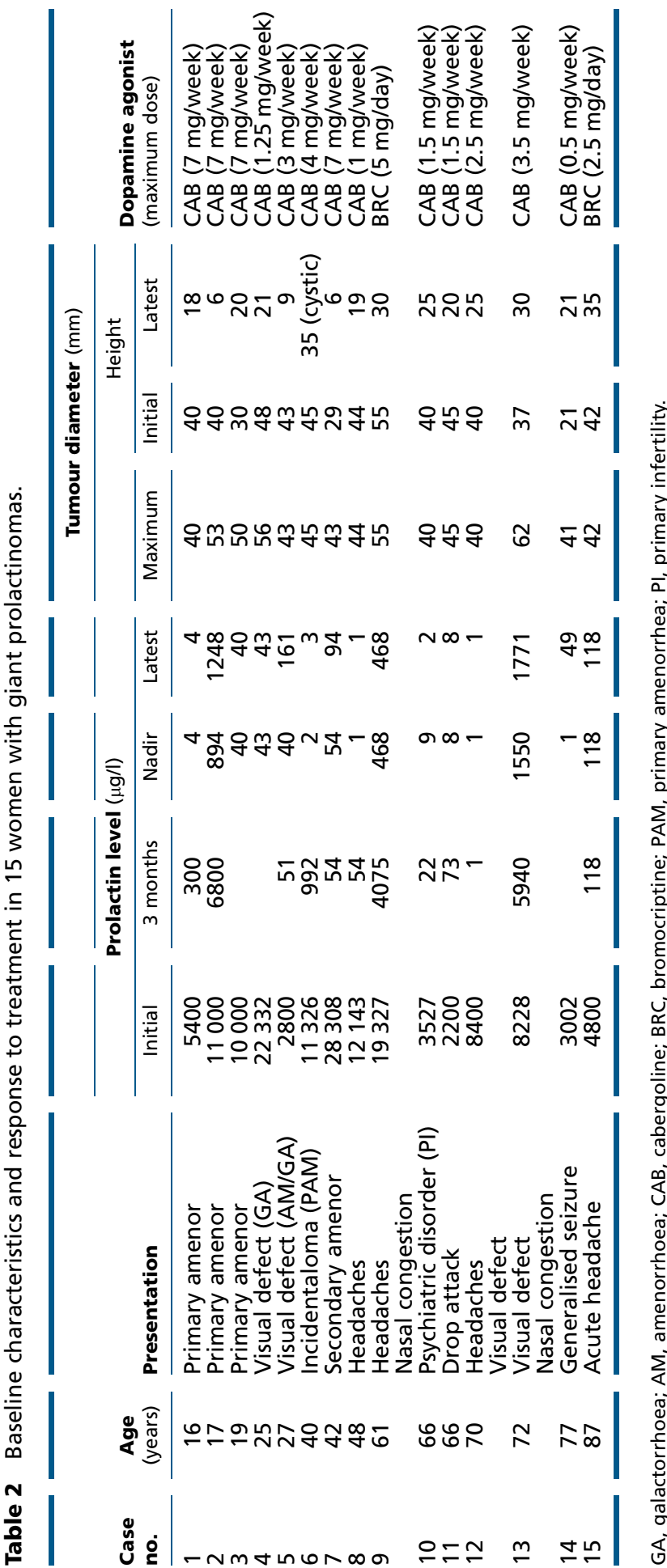

with persistent hyperprolactinaemia was still on a dose $<1.5 \mathrm{mg} /$ week. Medical treatment was complicated in four of the 34 patients by the occurrence of cerebrospinal fluid rhinorrhoea (Table 1, case nos 14 and 16 as well as one case in the series from Acharya et al. (11); Table 2, case no. 3).

From our population of 15 patients (Table 2), 14 received DAs as primary therapy and a significant reduction in tumour diameter $(\geq 30 \%)$ was observed in all but three patients: case no. 6 , who exhibited a cystic transformation of the tumour; case no. 13, who also demonstrated hormonal resistance to cabergoline; and case no. 14, who at the time of evaluation had only received a short course of low-dose bromocriptine treatment. MEN1 syndrome was recognised in one case (Table 2, case no. 1). Familial history was negative in all other cases and a search for MEN1 (Table 2, case nos 6 and 8) or AIP (Table 2, case nos 4 and 8) mutation was negative.

\section{Discussion}

Giant pituitary adenomas are defined as tumours with the largest diameter of $4 \mathrm{~cm}$ or more. This particular extension has been fixed arbitrarily (20), the same $4 \mathrm{~cm}$ diameter being used to classify aneurysms as giant. However, the tumour size at diagnosis may point to specific aspects in the pathogenesis of pituitary adenomas. Very large tumours have a different clinical presentation, most of them are invasive, and the arbitrary division of pituitary tumours into microadenomas, macroadenomas and giant adenomas is helpful to compare the results of treatment, as tumour size is a relevant prognostic marker for the success of treatment. As far as prolactinomas are concerned, most giant tumours are treated medically with cabergoline, without histological diagnosis. Serum prolactin levels generally parallel tumour size and giant invasive prolactinomas are typically associated with prolactin levels $>1000 \mu \mathrm{g} / \mathrm{l}$ (5). Most non-surgical series of giant prolactinomas published in the literature used as diagnostic criteria a serum prolactin level higher than $1000 \mu \mathrm{g} / \mathrm{l}$ $(1,3,7,11), 2000 \mu \mathrm{g} / \mathrm{l}$ (21), $3000 \mu \mathrm{g} / \mathrm{l}$ (2) or even $5000 \mu \mathrm{g} / \mathrm{l}(22)$. In one series (9), prolactin level was reported as $>200 \mu \mathrm{g} / \mathrm{l}$, but difficulties at the laboratory were mentioned and accurate prolactin levels were not available in some cases. In a recent surgical series including ten patients (all men) with monohormonal giant prolactinoma (23), the serum prolactin level ranges from 365 to $7556 \mu \mathrm{g} / \mathrm{l}$. All but one tumour were invasive. There were two cases with a serum prolactin below $1000 \mu \mathrm{g} / \mathrm{l}$ : the only 


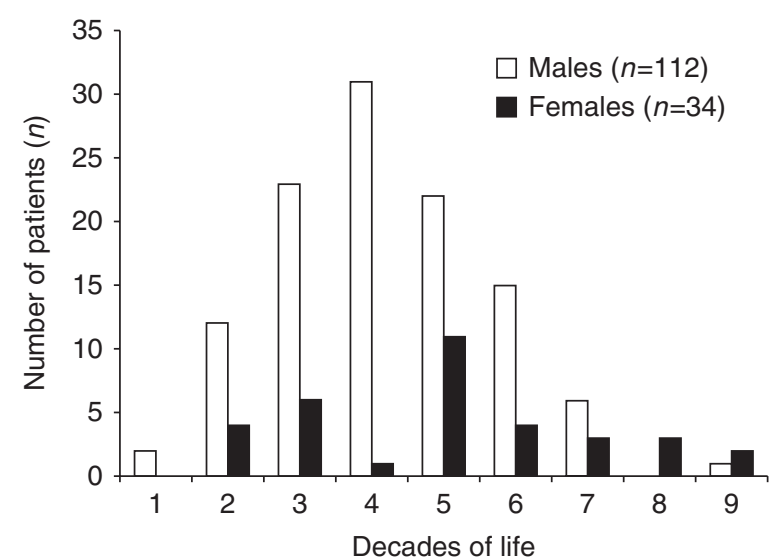

Figure 1

Distribution of giant prolactinomas by decades of life in a series of 112 unselected men and in 34 women.

non-invasive tumour $(365 \mu \mathrm{g} / \mathrm{l})$ and another one whose serum prolactin level was $985 \mu \mathrm{g} / \mathrm{l}$ (personal data from G Raverot \& J Trouillas). Thus, although a lower prolactin level may be consistent with the presence of a giant prolactinoma, in the setting of this retrospective non-surgical series and in order to compare with the existing literature, we decided to use as diagnostic criteria a tumour diameter $>40 \mathrm{~mm}$ and a serum prolactin concentration higher than $1000 \mu \mathrm{g} / \mathrm{l}$.

Giant prolactinomas, as defined above, are relatively rare and published series generally include about ten patients with either no $(1-3,21,23), 1$ (22) or 2 (7) women respectively. The series from Acharya et al. (11) was an exception including five men and five women. The largest series published to date (9) consisted of four women and 16 men but used a less stringent criterion for inclusion (serum prolactin $>200 \mu \mathrm{g} / \mathrm{l}$ ), as already mentioned. From the present review, it can be established that women represent about $10 \%(13 / 125)$ of patients with a giant prolactinoma.

It appears that men with giant prolactinomas are younger at diagnosis than women and that all cases aged $<15$ years described until now $(n=10)$ are boys. This is in keeping with our previous study (24) demonstrating that the gender-related difference in tumour size is not only due to a longer delay before diagnosis in male compared with female patients but rather to an overall greater growth potential of prolactinomas among males. Data collected here, however, illustrate that, at variance with a common idea, the clinical symptoms of hyperprolactinaemia in women (amenorrhoea and/or galactorrhoea) do not always lead to a prompt diagnosis of the disease and that only a small subset of female prolactinomas will show an important growth over time. In the present review, the delay before diagnosis ranged from 2 to more than 30 years. This is not a unique feature of giant prolactinomas. In the historical study by Nabarro (25), although most tumours were intrasellar at diagnosis (84\%), 15 of the 83 patients with secondary amenorrhoea had had the condition for more than 10 years. In another series (24), although eight of 51 women were amenorrhoeic for more than 10 years, six had microadenomas.

Nowadays, in Europe, 35\% of women of childbearing age receive either an oral contraception, which can maintain regular menstrual bleeding despite hyperprolactinaemia, or an intrauterine device, which, if releasing levonorgestrel, can lead to amenorrhoea irrespective of the prolactin level. Thus, in many situations, the clinician can no more rely on the hallmark of hyperprolactinaemia, namely the menstrual disturbance. On the other hand, the prevalence of galactorrhoea is roughly 50\% (25) but decreases in long-standing hypo-oestrogenic states with a proportion of one of three in our series. Thus, as in men, in case of a giant skull base tumour, prolactinoma should always be excluded, irrespective of age and/or duration of amenorrhoea and/or presence of galactorrhoea, in order to avoid errors in the management of these women. In this setting, prolactin assay should be done after serum sample dilution to overcome a potential 'hook effect' due to very high antigen levels (10), which can constitute another cause of diagnostic delay.

Cabergoline should be the first-line therapy for these tumours, although only a minority will be controlled with standard doses (21). Most giant prolactinomas are invasive towards the cavernous sinus ( 14 of 15 in the present series) and invasive macroprolactinomas have been shown to be less responsive to DA therapy (19). An overview of the response to treatment with cabergoline observed in series of at least three patients with previously untreated giant prolactinoma is shown in Table 3 . Among the 16 female patients, only three normalised their prolactin level with weekly doses $<2.0 \mathrm{mg}$ and five other women did so on higher doses. The response rate observed in men, although slightly higher, is not significantly different. The therapeutic approach proposed when the response to cabergoline is insufficient has recently been reviewed elsewhere (26). It should be noticed that there are no data regarding the use of temozolomide in women with giant prolactinomas and that radiotherapy was performed in only two cases (see Table 1) but resulted in visual loss in one (9).

The fact that only a subset of female prolactinomas will show an important growth potential with time is 
Table 3 Overview of the response to treatment with cabergoline in previously untreated giant prolactinomas in men and women. Tumour shrinkage was considered significant when obtaining a $>30 \%$ reduction in tumour diameter and/or a $>65 \%$ reduction in tumour volume.

\begin{tabular}{|c|c|c|c|}
\hline References & $\begin{array}{l}\text { Gender } \\
\text { (no. of patients) }\end{array}$ & $\begin{array}{l}\text { PRL } \\
\text { normalisation } \\
(n)\end{array}$ & $\begin{array}{l}\text { Significant } \\
\text { tumour } \\
\text { shrinkage }(n)\end{array}$ \\
\hline (2) & Men $(n=5)$ & $3 / 5$ & $2 / 5$ \\
\hline (21) & Men $(n=10)$ & $9 / 10$ & $6 / 10$ \\
\hline (3) & Men $(n=10)$ & $6 / 10$ & $10 / 10$ \\
\hline (37) & Men $(n=3)$ & $3 / 3$ & ND \\
\hline \multirow[t]{2}{*}{ (11) } & Men $(n=4)$ & $3 / 4$ & $2 / 3$ \\
\hline & Women $(n=4)$ & $2 / 4$ & $1 / 2$ \\
\hline Present study & $\begin{array}{l}\text { Women } \\
\qquad(n=12)\end{array}$ & $6 / 12$ & $10 / 12$ \\
\hline \multirow[t]{2}{*}{ Total } & $\operatorname{Men}(n=32)$ & 24/32 (75\%) & $20 / 28(71 \%)$ \\
\hline & $\begin{array}{l}\text { Women } \\
\qquad(n=16)\end{array}$ & $8 / 16(50 \%)$ & $11 / 14(79 \%)$ \\
\hline
\end{tabular}

likely dependant on factors limiting angiogenesis (27). Histological data (28) indicating that prolactinomas are often highly vascularised in men, whereas the tumours frequently are haemorrhagic in women, were recently confirmed by magnetic resonance imaging studies (29). However, the mechanism explaining this gender-related difference in blood supply remains unknown. Five cases of giant prolactinomas in women come from the same Indian series of ten patients (11). The authors postulated that the overrepresentation of women may be due to a late presentation related to economic and social factors in their country. However, the relatively young age of their patients (ranging from 17 to 50 years) compared with the whole series (median age at diagnosis 44 years) does not support this hypothesis and an impact of environmental (30) or genetic factors $(31,32)$ cannot be ruled out. In our series, only one patient was found to have MEN1 while other patients had no family history of pituitary adenoma nor hypercalcaemia and/or MEN1-associated lesions. A search for mutation of the AIP and MEN1 genes was performed only in two cases but was negative.

A striking point is the observation of a gender-related difference in the distribution of giant prolactinomas by decades of life, indicating once more that the biology of prolactinomas is different in males and females. In men, the occurrence of giant prolactinomas has a peak during the fourth decade of life and then decreases sharply. A similar pattern is observed in other tumours such as testis cancer and points towards a 'frailty' effect, with some men having a much greater risk of developing the tumour than the majority of men (33). After those with the highest risk having developed the tumour, the remaining population consists mainly of individuals who are virtually non-susceptible to the disease. In women, when considering a large series of micro- and macroprolactinomas $(n=709)$, a marked peak occurrence is observed in the third and fourth decades of life (34). The distribution of giant prolactinomas is different with only one case of 34 diagnosed during the fourth decade while other cases seem to be distributed in two age groups: a small group with early onset that may reflect a stronger hereditary pathogenesis and a larger late-onset group where a number of genetic or epigenetic events are probably required to reach a giant size. The woman with MEN1 syndrome was diagnosed at the age of 16 years. Intriguingly, the four patients responding to standard doses of cabergoline belonged to the late-onset group. Patients with MEN1 or AIP mutation have been reported to be younger at diagnosis with tumours that are larger and less responsive to treatment $(31,32)$.

A similar bimodal frequency distribution among age groups of females was recently observed for meningiomas (35). Like prolactinomas, meningiomas are more frequent among women while male gender is associated with higher grade tumours. In meningiomas, clinical and histopathological studies have shown an inverse relationship between the progesterone receptor expression level and tumour grade and recurrence. Available data regarding expression of sex steroid receptors in pituitary adenomas are scarce, but in one study (36), microadenomas were characterised by a higher progesterone receptor expression than macroadenomas, while haemorrhagic macroadenomas had a high oestrogen receptor expression. Thus, the expression of sex steroid receptors and their relationship with angiogenesis should be further studied in prolactinomas and may help to elucidate part of the gender differences observed in the behaviour of these tumours. In addition, the fact that some giant prolactinomas might already occur in very young boys before the onset of puberty should keep open the possible contribution of neonatal sex steroid imprinting.

In conclusion, only $10 \%$ of giant prolactinomas occur in women and they seem to be equally responsive to DAs similar to tumours found in men. In contrast to the unimodal distribution observed in the male gender, female giant prolactinomas seem to be distributed according to two age groups, with a larger late-onset peak. If confirmed in further studies, the observed age-incidence curves may help to establish a multistage model of tumorigenesis including a frailty effect. 


\section{Declaration of interest}

The authors declare that there is no conflict of interest that could be perceived as prejudicing the impartiality of the research reported.

\section{Funding}

This research did not receive any specific grant from any funding agency in the public, commercial or not-for-profit sector.

\section{References}

1 Shrivastava RK, Arginteanu MS, King WA \& Post KD. Giant prolactinomas: clinical management and long-term follow-up. Journal of Neurosurgery 200297 299-306. (doi:10.3171/jns.2002. 97.2.0299)

2 Corsello SM, Ubertini G, Altomare M, Lovicu RM, Migneco MG, Rota CA \& Colosimo C. Giant prolactinomas in men: efficacy of cabergoline treatment. Clinical Endocrinology $200358662-670$. (doi:10.1046/j.1365-2265.2003.01770.x)

3 Cho EH, Lee SA, Chung JY, Koh EH, Cho YH, Kim JH, Kim CJ \& Kim MS. Efficacy and safety of cabergoline as first line treatment for invasive giant prolactinoma. Journal of Korean Medical Science 200924 874-878. (doi:10.3346/jkms.2009.24.5.874)

4 Gillam MP, Molitch ME, Lombardi G \& Colao A. Advances in the treatment of prolactinomas. Endocrine Reviews 200627 485-534. (doi:10.1210/er.2005-9998)

5 Lundberg PO, Osterman PO \& Wide L. Serum prolactin in patients with hypothalamus and pituitary disorders. Journal of Neurosurgery 198155 194-199. (doi:10.3171/jns.1981.55.2.0194)

6 Cole DR, Lees PD \& Armitage M. A good wife, but never a mother.... Journal of the Royal Society of Medicine 199588 176P-178P

7 Saeki N, Nakamura M, Sunami K \& Yamaura A. Surgical indication after bromocriptine therapy on giant prolactinomas: effects and limitations of the medical treatment. Endocrine Journal 1998 45 529-537. (doi:10.1507/endocrj.45.529)

8 Al Sifri SN \& Raef H. The hook effect in prolactin immunoassays. Saudi Medical Journal 200425 656-659.

9 Wu ZB, Yu CJ, Su ZP, Zhuge QC, Wu JS \& Zheng WM. Bromocriptine treatment of invasive giant prolactinomas involving the cavernous sinus: results of a long-term follow up. Journal of Neurosurgery $2006 \mathbf{1 0 4}$ 54-61. (doi:10.3171/jns.2006.104.1.54)

10 Yener S, Comlekci A, Arda N, Men S \& Yesil S. Misdiagnosis due to the hook effect in prolactin assay. Medical Principles and Practice 200817 429-431. (doi:10.1159/000141512)

11 Acharya SV, Gopal RA, Menon PS, Bandgar TR \& Shah NS. Giant prolactinoma and effectiveness of medical management. Endocrine Practice 201016 42-46. (doi:10.4158/EP09221.OR)

12 Yang MS, Hong JW, Lee SK, Lee EJ \& Kim SH. Clinical management and outcome of 36 invasive prolactinomas treated with dopamine agonist. Journal of Neuro-Oncology 2011104 195-204. (doi:10.1007/s11060-010-0459-3)

13 Clayton RN, Webb J, Heath DA, Dunn PJ, Rolfe EB \& Hockley AD. Dramatic and rapid shrinkage of a massive prolactinoma with bromocriptine: a case report. Clinical Endocrinology 198522 573-581. (doi:10.1111/j.1365-2265.1985.tb02992.x)

14 Khan EG \& Howlett TA. Two macroprolactinomas presenting with neurological signs. Journal of the Royal Society of Medicine $1995 \mathbf{8 8}$ 111P-112P.

15 Siegel RD \& Lee SL. Pneumocephalus and cerebrospinal fluid rhinorrhea after bromocriptine therapy of an invasive prolactinoma: a case report and review of the literature. Endocrinologist 19966 148-152. (doi:10.1097/00019616-199603000-00012)
16 Zikel OM, Atkinson JLD \& Hurley DL. Prolactinoma manifesting with symptomatic hydrocephalus. Mayo Clinic Proceedings 199974 475-477. (doi:10.4065/74.5.475)

17 Freda PU, Andreadis CI, Khandji AG, Khoury M, Bruce JN, Jacobs TP \& Wardlaw SL. Long-term treatment of prolactin-secreting macroadenomas with pergolide. Journal of Clinical Endocrinology and Metabolism 200085 8-13. (doi:10REF17=10.1210/jc.85.1.8)

18 Harzallah F, Harzallah L, Ben Brahim A, Mekaouer A \& Slimane H. Macroadénome à prolactine révélé par une exophtalmie. Journal Français d'Ophtalmologie 200932 133e1-133e3. (doi:10.1016/j.jfo.2008.12.005)

19 Delgrange E, Daems T, Verhelst J, Abs R \& Maiter D. Characterization of resistance to the prolactin-lowering effects of cabergoline in macroprolactinomas: a study in 122 patients. European Journal of Endocrinology 2009160 747-752. (doi:10.1530/EJE-09-0012)

20 Symon L, Jakubowski J \& Kendall B. Surgical treatment of giant pituitary adenomas. Journal of Neurology, Neurosurgery, and Psychiatry 197942 973-982. (doi:10.1136/jnnp.42.11.973)

21 Shimon I, Benbassat C \& Hadani M. Effectiveness of long-term cabergoline treatment for giant prolactinoma: study of 12 men. European Journal of Endocrinology 2007156 225-231. (doi:10.1530/EJE-06-0646)

22 Davis JR, Sheppard MC \& Heath DA. Giant invasive prolactinoma: a case report and review of nine further cases. Quarterly Journal of Medicine 1990275 227-238.

23 Raverot G, Wierinckx A, Dantony E, Auger C, Chapas G, Villeneuve L, Brue T, Figarella-Branger D, Roy P, Jouanneau E et al. Prognostic factors in prolactin pituitary tumors: clinical, histological, and molecular data from a series of 94 patients with a long postoperative follow-up. Journal of Clinical Endocrinology and Metabolism 201095 1708-1716. (doi:10.1210/jc.2009-1191)

24 Delgrange E, Trouillas J, Maiter D, Donckier J \& Tourniaire J. Sex-related difference in the growth of prolactinomas: a clinical and proliferation marker study. Journal of Clinical Endocrinology and Metabolism 199782 2102-2107. (doi:10.1210/jc.82.7.2102)

25 Nabarro JD. Pituitary prolactinomas. Clinical Endocrinology 198217 129-155. (doi:10.1111/j.1365-2265.1982.tb01573.x)

26 Moraes A, Marques dos Santos Silva C, Vieira Neto L \& Gadelha MR. Giant prolactinomas: the therapeutic approach. Clinical Endocrinology 2013.

27 Garcia de la Torre N, Turner HE \& Wass JA. Angiogenesis in prolactinomas: regulation and relationship with tumour behaviour. Pituitary 20058 17-23. (doi:10REF27=10.1007/s11102005-5081-6)

28 Delgrange E, Sassolas G, Perrin G, Jan M \& Trouillas J. Clinical and histological correlations in prolactinomas, with special reference to bromocriptine resistance. Acta Neurochirurgica 2005147 751-758. (doi:10.1007/s00701-005-0498-2)

29 Sarwar K, Huda M, Van de Velde V, Hopkins L, Luck S, Preston R, McGowan B, Carroll P \& Powrie J. The prevalence and natural history of pituitary haemorrhage in prolactinoma. Journal of Clinical Endocrinology and Metabolism 201398 2362-2367. (doi:10.1210/jc. 2013-1249)

30 Cannavò S, Ferraù F, Ragonese M, Curtò L, Torre ML, Magistri M, Marchese A, Alibrandi A \& Trimarchi F. Increased prevalence of acromegaly in a highly polluted area. European Journal of Endocrinology 2010163 509-513. (doi:10.1530/EJE-10-0465)

31 Trouillas J, Labat-Moleur F, Sturm N, Kujas M, Heymann MF, Figarella-Branger D, Patey M, Mazucca M, Decullier E, Vergès B et al. Pituitary tumors and hyperplasia in multiple neoplasia type 1 syndrome (MEN1): a case-control study in a series of 77 patients versus 2509 non-MEN1 patients. American Journal of Surgical Pathology 200832 534-543. (doi:10.1097/PAS. 0b013e31815ade45)

32 Tichomirowa MA, Barlier A, Daly AF, Jaffrain-Rea ML, Ronchi C, Yaneva M, Urban JD, Petrossians P, Elenkova A, Tabarin A et al. High 
prevalence of AIP gene mutations following focused screening in young patients with sporadic pituitary macroadenomas. European Journal of Endocrinology 2011165 509-515. (doi:10.1530/EJE-11-0304)

33 Moger TA, Aalen OO, Halvorsen TO, Storm HH \& Tretli S. Frailty modelling of testicular cancer incidence using Scandinavian data. Biostatistics 20045 1-14. (doi:10.1093/ biostatistics/5.1.1)

34 Mindermann T \& Wilson CB. Age-related and gender-related occurrence of pituitary adenomas. Clinical Endocrinology 199441 359-364. (doi:10.1111/j.1365-2265.1994.tb02557.x)
35 Backer-Grøndahl T, Moen BH \& Torp SH. The histopathological spectrum of human meningiomas. International Journal of Clinical and Experimental Pathology 20125 231-242.

36 Jaffrain-Rea ML, Petrangeli E, Ortolani F, Fraioli B, Lise A, Esposito V, Spagnoli LG, Tamburrano G, Frati L \& Gulino A. Cellular receptors for sex steroids in human pituitary adenomas. Journal of Endocrinology 1996 151 175-184. (doi:10.1677/joe.0.1510175)

37 Yarman S, Kurtulmus N \& Bilge A. Optimal effective doses of cabergoline and bromocriptine and valvular lesions in men with prolactinomas. Neuroendocrinology Letters 201233 340-346.

Received 20 June 2013

Revised version received 4 September 2013

Accepted 2 October 2013 